\title{
Evaluasi Pelaksanaan Pembelajaran Daring dalam Masa Pandemi COVID-19 pada Tingkat Madrasah di Kabupaten Bengkulu Tengah
}

\section{Rupiah}

Kementerian Agama Wilayah Kabupaten Bengkulu Tengah, Indonesia Korespondensi:piahnataris@gmail.com

\begin{tabular}{c}
\hline Info Artikel \\
\hline Diterima 5 Maret \\
2021 \\
Disetujui 6 Mei \\
2021 \\
Dipublikasikan 8 \\
Mei 2021 \\
Keywords: \\
Respon Siswa, \\
Pandemi Covid-19 \\
Pembelajaran \\
Daring \\
\hline (C)19 Universitas \\
Muhammadiyah \\
Buton \\
Under the license \\
CC BY-SA 4.0 \\
cc) (1) () \\
BY sA
\end{tabular}

\section{Abstrak}

Penelitian ini secara umum bertujuan untuk mengevaluasi murid, guru serta orang tua murid terhadap pembelajaran secara daring yang sudah diterapkan ke seluruh murid pada satuan pendidikan MI, MTs serta MA di daerah Kabupaten Bengkulu Tengah sepanjang adanya pandemi virus corona atau COVID-19. Data dalam bentuk informasi diambil dengan mengenakan kuesioner/angket yang disiapkan dalam wujud Google form serta tautan dikirimkan lewat Whats App kepada murid, guru dan orang tua murid. Sebanyak 49 murid, 42 orang tua murid serta 37 guru ikut dan berpartisipasi dalam riset ini. Periset memperoleh sebagian kenyataan terpaut pendidikan secara daring dalam masa pandemi COVID-19. Adapun yang pertama, RPP serta media pembelajaran dianalisa konteksnya oleh guru sebelum diberikan kepada murid. Kedua, media pembelajaran yang paling sering digunakan adalah WhatsApp. Berikutnya, minimnya akses serta kuota internet merupakan hambatan yang dialami oleh guru serta murid sepanjang pendidikan secara daring. Terakhir, murid, orang tua dan guru menginginkan kegiatan pembelajaran secara langsung dapat kembali dilaksanakan.

\section{Abstract}

This research generally aims to evaluate students, parents and teachers on daring learning that has been implemented by MI, MTs and MA in the Central Bengkulu Regency areas during the pandemi of COVID-19. Data was collected using a questionnaire prepared in a Google form and the link sent to students, parents and teachers by WhatsApp. Totally 49 students, 42 parents and 37 teachers participated in this research. The researchers received several facts related to daring learning during the COVID-19 pandemi. Firstly, the lesson plan and learning media are analyzed in context by the teacher before given to the students. Secondly, the learning media that is often used is WhatsApp. Furthermore, the lack of internet access and quota is an obstacle felt by teachers and students during daring learning. Finally, students, parents and teachers wish direct learning activities to be carried out again. 


\section{Pendahuluan [}

Pada akhir Desember tahun 2019 lalu, masyarakat dunia digemparkan adanya wabah pandemi virus corona. Severe acute respiratory syndrome coronavirus 2 (SARS-CoV-2) yang lebih dikenal dengan nama virus Corona adalah jenis baru dari coronavirus yang menular ke manusia. Menurut WHO (2020) hal ini ditetapkan karena wabah penyakit tersebut telah menyebar ke berbagai negara. Lebih lanjut menurut WHO, virus corona atau yang lebih dikenal dengan nama COVID-19 merupakan penyakit menular jenis baru yang sangat menular di ruang tertutup.

Pemerintah beserta pemangku kebijakan dibidang kesehatan di seluruh dunia berkerja sama untuk mencoba menghentikan penyebaran virus yang menghancurkan perekonomian hampir diseluruh negara. Masyarakatpun diminta untuk mengikuti arahan dari pemerintah seperti tetap dirumah karena pembatasan aktivitas manusia dapat membantu membatasi penyebaran virus. Sejalan dengan itu, pemerintah Indonesia melalui Kementerian Aparatur Sipil Negara Reformasi dan Birokrasi mengeluarkan kebijakan bagi para ASN di seluruh Indonesia agar dapat bekerja dari rumah atau work from home (WFH) untuk meminimalisasi penyeberaan virus corona dilingkungan kantor mengingat mobilitas yang sangat tinggi.

Selain itu, pemerintah dalam hal ini Kementerian Pendidikan dan Kebudayaan telah mengeluarkan perintah tegas untuk menutup sementara lembaga pendidikan dari taman kanak-kanak hingga perguruan tinggi, yang mana berdampak pada penyelenggaraan pendidikan di Indonesia. Kementerian Pendidikan dan Kebudayaan Republik Indonesia sudah mengeluarkan instruksi berbentuk surat edaran No 4 Tahun 2020, tentang penerapan kebijakan pembelajaran pada masa darurat penyebaran COVID-19. Dengan kata lain, sekolah harus tutup dalam waktu lama dan dalam waktu yang tidak pasti. Disisi lain, pihak guru diharuskan tetap menjalankan kegiatan sekolah dan untuk menemukan cara baru dalam proses pembelajaran kepada murid.

Pembelajaran secara daring telah beberapa kali diteliti di Indonesia selama terjainya penyebaran pandemi virus corona/COVID-19. Seperti yang dipaparkan (Rahayu, 2020) dalam hasil risetnya yang mengemukakan (1) Mahasiswa paa hakikatnya sudah memiliki fasilitas dasar yang dibutuhkan untuk pembelajaran secara daring; (2) Pelaksanaan pembelajaran daring/daring membuat jauh lebih fleksibel, dimana dapat mendorong pembelajaran mandiri dan merangsang semangat belajar bagi mereka; (3) Pembelajaran jarak jauh/daring mendorong perilaku social distancing dengan tujuan meminimalkan munculnya mahasiswa dalam jumlah besar sehingga dapat mengurangi kemungkinan penyebaran virus corona/COVID-19 di dalam lingkungan dan aktivitas kampus.

Lebih jauh, penelitian yang dilakukan oleh Setiawan \& Mufassaroh (2020) mengungkapkan jika murid belum secara optimal dalam menjalankan dan memahami literasi sains. Sesungguhnya, dengan adanya pandemi COVID-19 memiliki dampak positif yakni, semua elemen pendidikan baik guru, murid dan orang tua murid dipaksa untuk menerapkan pembelajaran daring. Berbagai macam model atau media pembelajaran secara daring dapat diajarkan baik kepada guru dan murid secara bersama-sama. Saat ini, tak ada alasan untuk menghindari pembelajaran secara daring. Untuk itu menurut Pujilestari (2020) untuk mencapai 
tujuan pembelajaran yang efisien dan efektif selama pandemi virus corona/COVID19, pihak sekolah dalam hal ini murid serta guru harus dibantu oleh pemerintah dalam mencari media pembelajaran terbaik.

Sampai detik ini, sekolah-sekolah yang berada dibawah naungan Kementerian Agama wilayah Kabupaten Bengkulu Tengah belum memberikan laporan resmi terkait hasil pembelajaran daring yang dilakukan oleh murid. Hal tersebut menurut Udiutomo (2011) sangat disayangkan karena kualitas pelayanan dapat ditentukan oleh kepuasan murid. Oleh karena itu, tanggapan murid, orang tua murid, serta guru terhadap pembelajaran daring selama wabah pandemi virus corona/COVID-19 sangatlah krusial dikarenakan akan dijadikan salah satu bentuk penilaian kinerja masing-masing sekolah. Diharapkan penelitian ini dapat memberikan evaluasi yang kompreh ensif terhadap proses pembelajaran daring pada sekolah khususnya pada tingkat dasar. Adapun yang menjadi pembaharuan dalam penelitian ini adalah adanya penggunaan 3 variabel yang saling terikat dalam proses pembelajaran daring yakni, guru, siswa dan orang tua murid khususnya di wilayah Kabupaten Bengkulu Tengah yang bisa menjadi acuan utamanya bagi pemerintah setempat.

\section{Metode Penelitian}

Penelitian ini menggunakan penelitian observasional. Adapun menurut Sugiyono (2014) memaparkan bahwa observasi sendiri ialah suatu proses yang kompleks dimana tersusun dari berbagai proses biologis dan psikolgis. Ada 2 proses paling penting didalamnya yakni proses pengamatan dan ingatan. Dalam penelitain ini juga bersifat deskriptif dimana guru, murid, serta orang tua berpartisipasi sebagai responden. Tujuan penelitian ini adalah untuk mengevaluasi pembelajaran daring murid MI, MTs dan MA yang berada dibawah naungan Kementerian Agama Wilayah Kabupaten Bengkulu Tengah. Jumlah sekolah yang dijadikan populasi yakni sekolah pada MI, MTs dan MA di Kabupaten Bengkulu Tengah. Adapun teknik pengambilan sampel yang digunakan yakni cluster random sampling, yang mana penelitian ini berfokus pada suatu hal pada bagian-bagian yang berbeda di dalam suatu kelompok.

Adapun data primer dalam penelitian ini dikumpulkan melalui angket yang di isi secara daring oleh responden melalui aplikasi google forms. Sedangkan, data sekunder dikumpu lkan secara random dari berbagai sumber ilmiah yang relevan, seperti hasil publikasi jurnal, berita media masa dan lain-lain. Angket penelitian ini mencakup beberapa hal, yaitu: 1) persepsi guru, murid dan orang tua, 2) bagaimana proses pembelajaran secara daring dari rumah, dan 3) dampak kebijakan belajar dari rumah bagi guru, murid dan orang tua murid. Kemudian data yang diperoleh dianalisis, kemudian diolah dalam bentuk persentase, lalu dijelaskan secara kualitatif dan didukung oleh temuan sebelumnya.

\section{Hasil dan Pembahasan}

Riset ini secara komprehensif mengevaluasi tanggapan guru, murid serta orang tua murid terhadap pembelajaran daring di Kabupaten Bengkulu Tengah mulai akhir Desember 2020 hingga pertengahan Februari 2021. Berikut tampilan demografi responden dalam penelitian ini. 


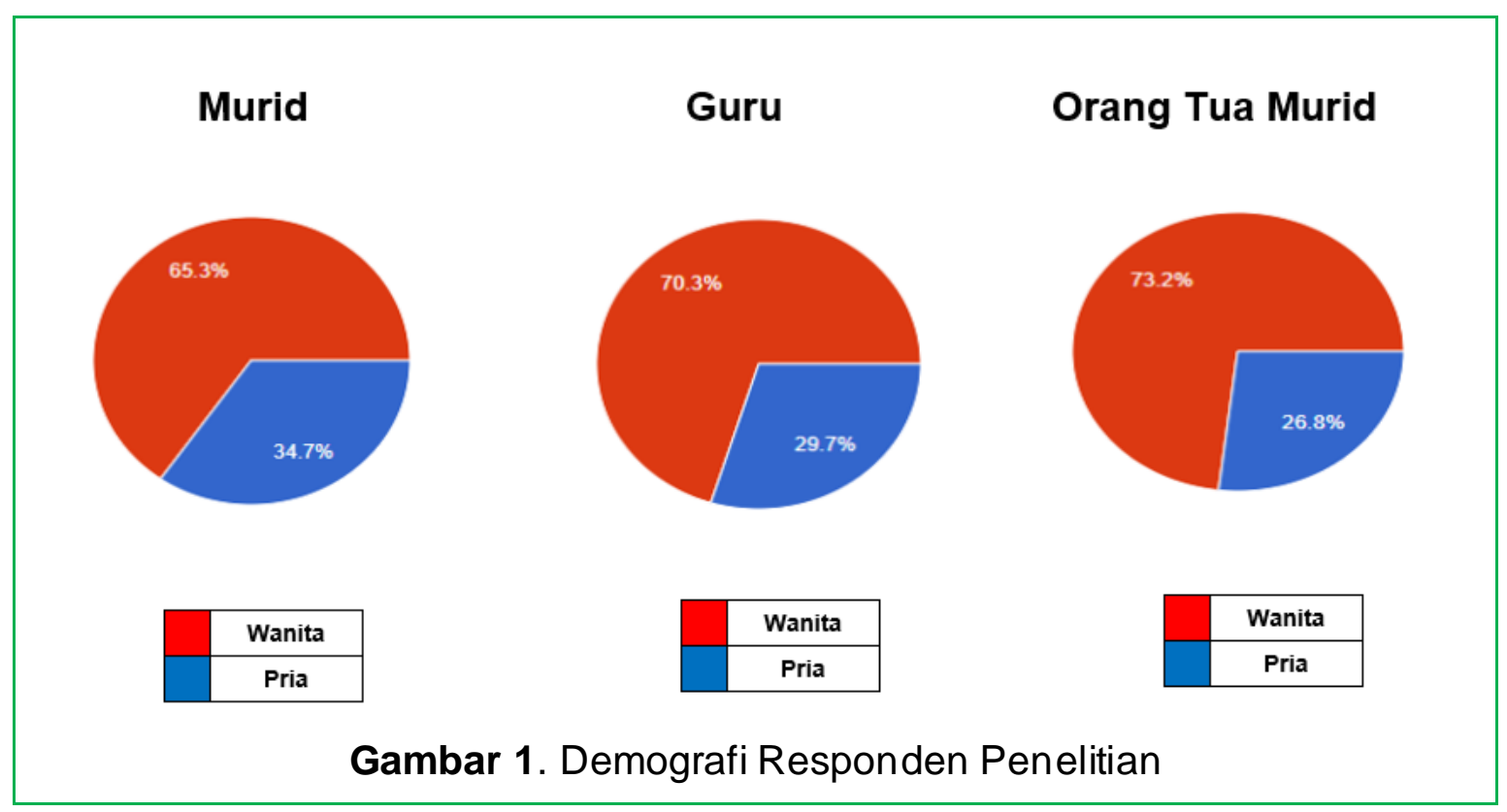

Berdasarkan gambar 1 dapat dilihat terlihat total keseluruhan responden sebagian besar adalah wanita, baik murid, guru maupun orang tua murid. Jumlah pria yang bersekolah lebih sedikit jika dibandingkan dengan wanita. Ini selaras dengan pandangan Winarti (2017), yang menerangkan bahwa memang jumlah guru pria lebih sedikit dibandingkan wanita. Beberapa hasil riset sebelumnya juga mengatakan demikian seperti paparan Aisyah et al. (2019) dimana para ayah cenderung kurang terlibat dalam proses pendidikan anakanak mereka. Tentu, jika ini dibiarkan secara terus menerus akan menyebabkan anak akan kehilangan sosok atau figure ayahnya. Lebih jauh Alawi (2016), berpendapat bahwa pekerjaan seorang ayah sebagai salah satu penyebab anak dan ayahnya jarang bertemu. Disisi lain, seorang ayah seharusnya dapat membagi porrsi antara pekerjaan dan juga keluarga. Pekerjaan memang sangatlah penting agar dapat menyambung hidup, namun yang tidak kalah penting adalah mendidik anak.

Dalam masa pandemi seperti saat ini, guru banyak menggunakan berbagai macam media pembelajaran baik secara daring maupun tidak. Bahkan meski di sekolah yang sama, media pembelajaran yang digunakan guru dapat berbeda. Namun demikian, hasil penelitian menunjukan bahwa WhatsApp masih menjadi primadona dalam menyampaikan atau mengumpulkan tugas karena sangat mudah dioperasikan seperti yang diperlihatkan 


\section{Media Pembelajaran Yang Digunakan Murid}

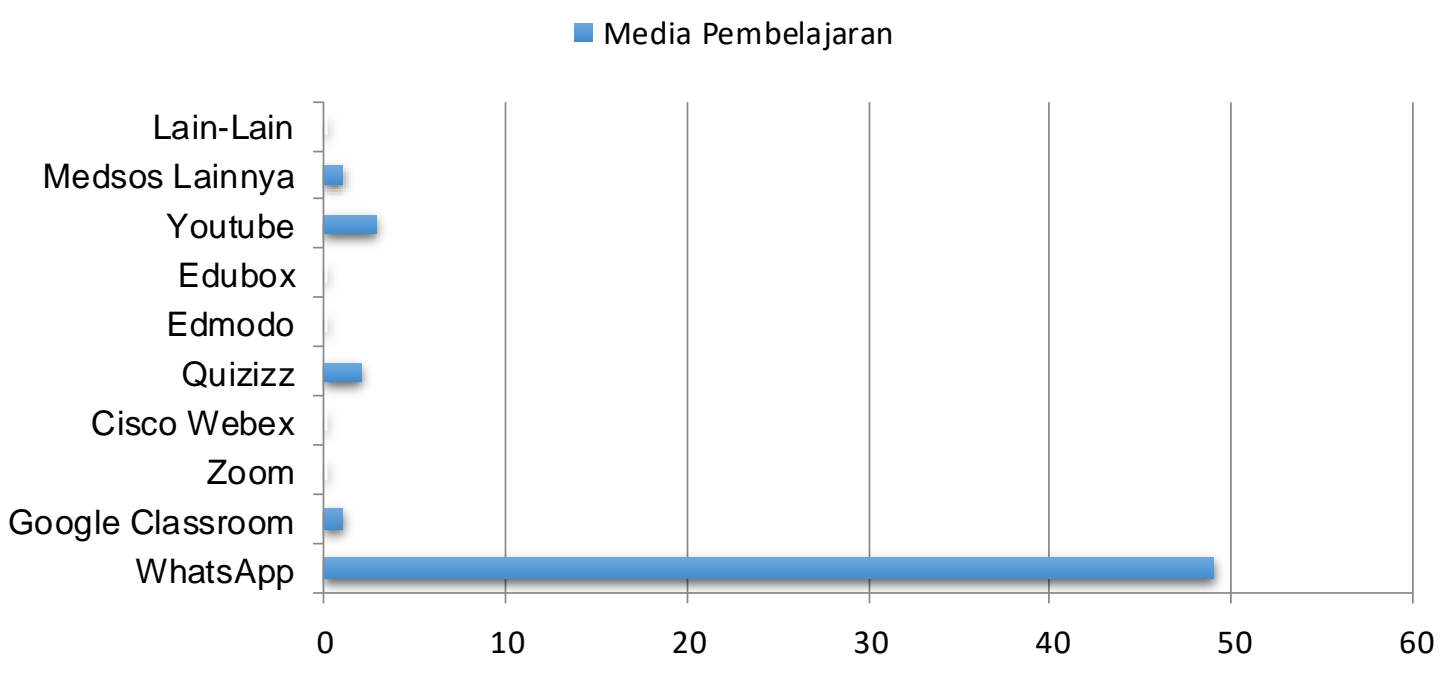

Gambar 2. Demografi Responden Penelitian

Setelah menyebarkan angket, murid diajak untuk memilih beberapa jawaban pada media yang digunakan dalam pembelajaran daring. Alhasil, WhatsApp menjadi pilihan utama mahasiswa dengan nilai persentase $100 \%$ atau 49 responden. Hal tersebut tidak mengherankan, karena WhatssApp dapat terkoneksi secara langsung dan cepat dengan ponsel mereka. Lebih lanjut (Citra, 2018) mengklarifikasi 5 fakta mengapa WhatsApp menjadi aplikasi primadona di Indonesia:

1. WhatsApp memiliki aplikasi obrolan sederhana yang tidak memerlukan kata sandi.

2. Langsung terhubung ke nomor di telepon/kontak seluler, cukup simpan nomor telepon, lalu Anda dapat melakukan sinkronisasi dengan kontak tersebut. Tidak perlu meminta ID atau PIN terlebih dahulu.

3. Alternatif yang praktis sebagai pengganti SMS. WhatsApp masih menjadi pilihan yang tepat dan praktis. Karena kita tidak perlu repot mengingat ID atau PIN kontak, yang sudah pasti memakan waktu.

4. Media yang tidak melakukan "pelacakan". WhatsaApp memiliki program telepon antarwajah yang sederhana untuk mengobrol.

5. Program telepon antar wajah yang sederhana, mudah dipahami dan data Internet yang murah, gratis dan tidak ada iklan

Media selanjutnya yang paling banyak dimanfaatkan oleh murid sebagai media alam hal pembelajaran adalah Youtube $(6,1 \%)$ dan Quizizz $(4,1 \%)$. Hal ini disebabkan penggunaan Android memudahkan murid dalam mengoperasikan media pembelajaran. Seperti yang kita ketahui bersama, Android merupakan perangkat buatan Google dan sudah tersinkronisasi dengan semua aplikasi buatan Google, sehingga guru dan murid tidak perlu repot dalam mendaftar kembali. Dari hasil penelitian, beberapa media sosial lain seperti Facebook, Instagram dan Twitter dengan persentase sekitar 21,6\% dan Youtube sekitar 5,4\% 
banyak digunakan guru untuk pembelajaran daring/daring selama wabah pandemi virus corona/ COVID-19.

\subsection{Respon Murid}

Tujuan kuesioner diberikan kepada murid adalah agar mereka mengumpulkan informasi berupa reaksi mereka terhadap pembelajaran daring selama wabah pandemi virus corona/COVID-19. Penelitian ini mengukur 10 indikator. Tabel 1 di bawah ini mencantumkan hasil pengolahan data sebagai berikut.

\section{Indikator Respon Murid}

\section{Respon Murid (\%)}

\begin{tabular}{lll} 
& Ya & Tidak \\
\hline Murid mengerti penyebab diberlakukannya belajar daring & 95.9 & 4.1 \\
\hline Murid mengerti informasi/ tugas yang diberikan oleh guru & 91.8 & 8.2 \\
\hline $\begin{array}{l}\text { Murid merasa persiapan yang dilakukan guru dalam pembelajaran } \\
\text { daring sudah maksimal }\end{array}$ & 89.8 & 10.2 \\
\hline Murid selalu mengikuti pembelajaran/ mengerjakan tugas dari guru & 93.9 & 6.1 \\
\hline $\begin{array}{l}\text { Murid merasa pembelajaran daring yang dilaksanakan guru sudah } \\
\text { efektif }\end{array}$ & 79.6 & 20.4 \\
\hline Murid bahagia belajar daring dari rumah & 63.3 & 36.7 \\
\hline Murid merasa dibebani dengan tugas yang diberikan oleh guru & 59.2 & 40.8 \\
\hline $\begin{array}{l}\text { Murid memiliki kendala terkait akses internet selama pembelajaran } \\
\text { daring berlangsung }\end{array}$ & 83.7 & 16.3 \\
\hline $\begin{array}{l}\text { Murid sering mengajukan pertanyaan kepada guru jika ada yang } \\
\text { belum dipahami }\end{array}$ & 89.8 & 10.2 \\
\hline $\begin{array}{l}\text { Murid merasa orang tua mendukung kebutuhan belajar } \\
\text { pembelajaran daring berlangsung }\end{array}$ & 89.8 & 10.2
\end{tabular}

Sumber: diadaptasi dari Sutia \& Sagita, 2020

Dari sudut pandang murid, pada tabel 1 terlihat fakta tentang pembelajaran daring selama pandemi COVID-19. Pertama, selama wabah pandemi COVID-19, semua murid sudah memahami tujuan program pembelajaran secara daring. Hal tersebut penting diketahui dan dipahami oleh murid mengingat virus ini adalah penyakit yang menular dan cara paling efektif alam mencegah itu terjadi adalah dengan menjaga jarak aman. Kedua, hampir seluruh murid merasa pembelajaran daring berjalan secara efektif, aplikasi yang digunakan dapat dipahami, murid dibantu oleh guru ketika mereka kesusahan, penilaian oleh guru yang sesuai, murid menerima banyak manfaat selama pembelajaran secara daring dan secara penuh didukung oleh orang tua mereka. Dari proses pembelajaran yang telah diberikan, dapat ditunjukan bahwa murid merasa puas. Kepuasan murid memperlihatkan jika pembelajaran sudah berjalan baik meskipun dalam keadaan pandemi seperti saat ini.

Namun di sisi lain, ternyata masih ada sejumlah kecil murid yang merasa tidak senang, tidak mengerjakan pekerjaan rumah, merasa bahwa persiapan guru tidak optimal, dibatasi oleh akses internet, dan guru tidak memberikan komentar selama pembelajaran. Ini dapat digunakan sebagai referensi untuk meningkatkan kualitas pembelajaran di masa depan. Permasalahan yang 
dihadapi oleh murid selama pembelajaran daring haruslah bisa dicarikan solusi oleh pihak guru dan sekolah. Persiapan maksimum harus dibuat oleh guru sehingga murid belajar dengan senang hati dan tetap tinggal di rumah. Lebih lanjut, umpan balik terhadap tugas yang dikerjakan oleh murid haruslah tetap diberikan oleh guru agar murid merasa dihargai. Komentar atau tanggapan yang diberikan oleh guru dapat membantu murid memahami kekurangan dan kelebihan mereka (Firman \& Rahayu, 2020).

Hal ini sejalan dengan pendapat Hattie (2009) yang menyebutkan bahwa hasil pembelajaran dapat ditingkatkan melalui timbal balik guru dan murid. Selain itu perlu adanya pendampingan kepada murid secara khusus yang dibatasi oleh akses internet, seperti jadwal kerja yang lebih fleksibel dan penerapan pembelajaran gabungan (tatap muka). Jika hal tersebut diimplementasikan dengan baik, maka hasil pembelajaran secara daring dapat terlihat secara maksimal. Artinya, guru dapat memberikan pembelajaran baik secara daring/luring dan siswa memahami materi yang disampaikan.

\subsection{Respon Orang Tua Murid}

Tujuan pemberian kuesioner/angket kepada orang tua murid adalah dengan mengumpulkan informasi tentang tanggapan/respon mereka terhadap pembelajaran daring selama wabah pandemi virus corona/COVID-19. Ini sejalan dengan perspektif (Dardiri, 2006) bahwa salah satu aspek dari kualitas pendidikan anak-anak adalah tanggung jawab bersama antara orang tua, guru dan sekolah. Berikut ini adalah hasil pemrosesan data respon orang tua, seperti yang ditunjukkan pada Tabel 2 di bawah ini.

Tabel 2. Respon Orang Tua Terhadap Pembelajaran Daring/Daring Selama Wabah Pandemi Virus Corona/COVID-19

\begin{tabular}{lcc}
\hline \multicolumn{1}{c}{ Indikator Respon Orang Tua Murid } & \multicolumn{2}{c}{$\begin{array}{c}\text { Respon Orang } \\
\text { Tua Murid (\%) }\end{array}$} \\
\cline { 2 - 3 } & Ya & Tidak \\
\hline $\begin{array}{l}\text { Orang tua murid mengerti diterapkannya pembelajaran secara } \\
\text { daring }\end{array}$ & 100 & 0 \\
\hline $\begin{array}{l}\text { Orang tua murid mengenali berkaitan dengan tugas serta agenda } \\
\text { murid sepanjang pembelajaran secara daring. }\end{array}$ & 88.1 & 11.9 \\
\hline $\begin{array}{l}\text { Orang tua murid merasa pembelajaran secara daring bermanfaat } \\
\text { bagi anaknya }\end{array}$ & 78.6 & 21.4 \\
\hline $\begin{array}{l}\text { Orang tua murid merasa pembelajaran secara daring yang } \\
\text { dilaksanakan guru sudah efektif }\end{array}$ & 59.5 & 40.5 \\
\hline $\begin{array}{l}\text { Orang tua murid senang melihat anak mereka melakukan } \\
\text { pembelajaran daring dari rumah }\end{array}$ & 33.3 & 66.7 \\
\hline $\begin{array}{l}\text { Orang tua murid merasa dibebani tugas yang diberikan oleh para } \\
\text { guru kepada anaknya }\end{array}$ & 38.1 & 61.9 \\
\hline $\begin{array}{l}\text { Orang tua murid merasa waktu pembelajaran secara daring perlu } \\
\text { diperpanjang }\end{array}$ & 14.3 & 85.7 \\
\hline $\begin{array}{l}\text { Orang tua murid sering bertanya kepada guru jika ada yang belum } \\
\text { dipahami }\end{array}$ & 69 & 31 \\
\hline $\begin{array}{l}\text { Orang tua murid merasa kurikulum yang dijalankan sekolah telah } \\
\text { cocok dengan suasana pandemi COVID- 19. }\end{array}$ & 81 & 19 \\
\hline
\end{tabular}

Sumber: diadaptasi dari Sutia \& Sagita, 2020 
Seperti yang dapat dilihat dari Tabel 2 di atas, selama pandemi COVID-19, orang tua dari semua murid memahami pentingnya belajar di rumah dan percaya bahwa kegiatan belajar daring bermanfaat bagi anak-anaknya. Hampir semua orang tua percaya bahwa pembelajaran secara daring tersebut hasilnya efektif dan kurikulum yang ditawarkan telah relevan. Namun, informasi mengenai jadwal pembelajaran daring masih banyak orang tua yang belum mengetahuinya. Hal ini menandakan kurangnya koordinasi antara sekolah dan orang tua murid. Hal tersebut sejalan dengan penelitian yang dipaparkan oleh Umar (2015) yang mengungkapkan pentingnya pencapaian akademik murid sangat berkaitan erat dengan peran dan dukungan orang tua. Jika orang tua murid selalu men dampingi anaknya ketika belajar, maka anak tersebut merasa didukung danmemberikan suntikan moral dalam proses pembelajaran daring. Mereka tidak akan merasa kesepian karena ada orang tua yang selalu siap menjadi tempat bertan ya selain guru.

\subsection{Tanggapan Guru}

Kuesioner guru bertujuan untuk mengumpulkan informasi dan tanggapan mereka terhadap pembelajaran secara daring (e-learning) selama wabah pandemi virus corona/COVID-19. Berikut adalah hasil pemrosesan data yang ditunjukkan pada Tabel 3 berikut.

Tabel 3. Respon Guru Terhadap Pembelajaran Daring Selama Wabah Pandemi Virus Corona/COVID-19

\begin{tabular}{|c|c|c|}
\hline \multirow[t]{2}{*}{ Indikator Respon Guru } & \multicolumn{2}{|c|}{$\begin{array}{l}\text { Respon Guru } \\
(\%)\end{array}$} \\
\hline & Ya & Tidak \\
\hline Guru memahami alasan pembelajaran daring. & 100 & 0 \\
\hline $\begin{array}{l}\text { Guru melaksanakan analisis kebutuhan modul/materi saat sebelum } \\
\text { pembelajaran daring. }\end{array}$ & 94.6 & 5.4 \\
\hline Sekolah harus membuat jadwal baru selama pandemi COVID-19 & 100 & 0 \\
\hline $\begin{array}{l}\text { Guru berkoordinasi dengan guru lainnya dalam merancang } \\
\text { pelaksanaan pembelajaran daring }\end{array}$ & 100 & 0 \\
\hline Guru memberikan umpan balik terhadap kegiatan pembelajaran daring & 94.6 & 5.4 \\
\hline Guru merasa senang dengan penerapan pembelajaran daring & 16.2 & 83.8 \\
\hline $\begin{array}{l}\text { Guru selama kegiatan pembelajaran daring mengalami kendala akses } \\
\text { dan kuota internet }\end{array}$ & 89.2 & 10.8 \\
\hline $\begin{array}{l}\text { Guru melakukan analisis sebelum menggunakan media pembelajaran } \\
\text { daring }\end{array}$ & 86.5 & 13.5 \\
\hline Guru dibantu sekolah dalam penyediaan sarana akses internet & 81.1 & 18.9 \\
\hline $\begin{array}{l}\text { Guru memberikan penilaian secara adil dan objektif walau } \\
\text { pembelajaran daring }\end{array}$ & 91.9 & 8.1 \\
\hline Guru merasa pembelajaran daring perlu diperpanjang & 8.1 & 91.9 \\
\hline
\end{tabular}

Sumber: diadaptasi dari Sutia \& Sagita, 2020

Beberapa fakta didapatkan dari tabel diatas terkait pembelajaran secara daring selama pandemik. Yang pertama, pembelajaran secara daring sudah dipahami oleh seluruh guru. Kedua, analisis kebutuhan materi pembelajaran telah dilakukan oleh guru, dikoordinasikan dengan guru mata pelajaran lainnya serta memberikan tanggapan/komentar kepada murid. Hal yang positif ini tentunya akan berpengaruh pada keefektifan pembelajaran yang berkelanjutan, karena berdampak paling baik bagi murid. Selanjutnya, banyak sekolah yang menyusun 
jadwal baru. Hal ini berdampak pada berkurangnya tugas rumah murid yang mana siswa bisa mengatur jadwal pembelajaran mereka dari satu guru kepada guru lainnya.

Meskipun begitu, ada beberapa catatan penting dari hasil kuesioner, yakni banyak "guru merasa tidak senang dengan penerapan pembelajaran daring" dengan presentasi $83.8 \%$. Selain itu, ada pula indikator "guru mengalami kendala akses dan kuota internet selama kegiatan pembelajaran daring" yang mendapatkan presentasi $89.2 \%$. Nilai-nilai ini cukuplah besar dan harus menjadi evaluasi bagi para pemangku kebijakan di Kantor Wilayah Kementerian Agama Kabupaten Bengkulu Tengah.

Merujuk reaksi murid, orang tua serta guru diatas terkait pembelajaran daring selama pandemi COVID-19, ada kenyataan menarik yang ditemukan peneliti. Beberapa diantaranya ialah kelancaran pembelajaran serta kepuasan murid sangat dipengaruhi oleh kesiapan yang dilakukan guru saat sebelum mengawali pembelajaran daring. Tidak hanya itu, hambatan terkait akses internet masih banyak dialami oleh guru dan murid. Lebih lanjut, koordinasi antara sekolah dengan guru, murid serta orang tua diharapkan bisa ditingkatkan sehingga penerapan pembelajaran daring lebih baik lagi kedepannya. Sekolah dan guru wajib merancang kegiatan pembelajaran yang tidak membebani murid dan membuat mereka betah serta senang tinggal di rumah sepanjang waktu. Tentu hal ini dapat sangat membantu untuk mempercepat pemulihan wabah virus corona/COVID-19, sehingga kegiatan pembelajaran kembali normal seperti sedia kala.

\section{Kesimpulan}

Berdasarkan analisis murid, orang tua, dan guru yang disebutkan di atas tentang tanggapan mereka terhadap berlangsungya pembelajaran secara daring selama wabah pandemi virus corona/COVID-19, ada temuan yang cukup penting telah ditemukan. Adapun pertama, media pembelajaran yang sangat banyak digunakan ialah WhatsApp. Berikutnya, ada sebagian hambatan yang dirasakan oleh guru serta orang tua murid dikala penerapan pembelajaran daring yakni terkait akses serta kuota internet. Ketiga, guru serta murid butuh dukungan sekolah dalam hal ini penyediaan akses internet menjadi sangat penting dan mendesak. Keempat, baik murid serta guru merindukan aktivitas pembelajaran tatap muka secara langsung.

Gambaran kesimpulan diatas dapat dijadikan rujukan atau pertimbangan dalam memberikan treatment untuk meningkatkan hasil pembelajaran guru terhadap murid dalam proses belajar dari rumah. Harus diakui bahwa kegiatan belajar daring bukan merupakan konsep pendidikan yang lazim dilakukan, sehingga hal yang wajar kemudian menimbulkan persepsi yang beragam. Kebijakan ini juga terkesan dilakukan dengan persiapan seadanya bahkan nyaris tanpa persiapan, sehingga masih banyak dijumpai kesenjangan dalam pelaksanaannya. Oleh karena itu, peneliti lain di masa yang akan datang disarankan untuk melakukan penelitian lebih lanjut di bidang ini, terutama dalam penerapan kebijakan dan pemanfaatan teknologi dalam dunia pendidikan.

\section{Ucapan Terima Kasih}


Dalam kesempatan ini, peneliti mengucapkan terima kasih kepada para responden baik murid, guru serta orang tua murid yang telah membantu memberikan data faktual mengenai pembelajaran daring yang tengah berlangsung. Selain itu juga, peneliti mengucapkan terima kasih banyak atas sponsor dan dukungan yang diberikan oleh Kantor Kementerian Agama Kabupaten Bengkulu Tengah sehingga penelitian ini berjalan dengan lancar sampai akhir.

\section{Daftar Pustaka}

Aisyah, D. S., Riana, N., \& Putri, F. E. (2019). Peran Ayah (fathering) Dalam Perkembangan Sosial Anak Usia Dini (Studi kasus pada anak usia 5-6 tahun di RA Nurhalim Tahun Pelajaran, 2018). Wahana Karya IImiah, 3(1).

Alawi, M. E. (2016). Pola Pengasuhan Anak Pada Keluarga Nelayan di Desa Perlis Kecamatan Berandan Barat Kabupaten Langkat. Universitas Negeri Medan.

Dardiri, A. (2006). Pengertian Pendidikan. In Ilmu Pendidikan.

Firman, F., \& Rahayu, S. (2020). Pembelajaran Daring di Tengah Pandemi COVID19. Indonesian Journal of Educational Science (IJES), 2(2), 81-89.

Hattie, J. (2009). Visible learning: A Synthesis of Meta-Analyses in Education. Routledge.

Organization, W. H. (2020). Coronavirus. WHO.

Pujilestari, Y. (2020). Dampak Positif Pembelajaran Daring Dalam Sistem Pendidikan Indonesia Pasca Pandemi Covid-19. ADALAH, 4(1).

Setiawan, A. R., \& Mufassaroh, A. Z. (2020). Lembar Kegiatan Siswa untuk Pembelajaran Jarak Jauh Berdasarkan Literasi Saintifik pada Topik Penyakit Coronavirus 2019 (COVID-19).

https://doi.org/https://doi.org/10.31237/osf.io/7tngk

Sugiyono. (2014). Metode Penelitian Kuantitatif, Kualitatif, dan Kombinasi (Mixed Methods). In Metode Penelitian Kuantitatif, Kualitatif dan R\&D. https://doi.org/10.3354/dao02420

Sutia, C., \& Sagita, S. (2020). Tanggapan Siswa, Orang Tua dan Guru terhadap Pembelajaran Jarak Jauh Selama Pandemi Covid-19 (Students, Parents and Teachers' Responses to Distance Learning During The Covid-19 Pandemic). Jurnal Inspirasi, 11(2), 156-165. https://doi.org/https://doi.org/10.35880/inspirasi.v11i2.141

Udiutomo, P. (2011). Analisa Tingkat Kepuasan Siswa Terhadap Layanan Program Smart Ekselensia Indonesia Tahun 2011. Jurnal Pendidikan Dompet Dhuafa. 1(1), 50-56.

Umar, M. (2015). Peranan Orang Tua Dalam Peningkatan Prestasi Belajar Anak. JURNAL EDUKASI: Jurnal Bimbingan Konseling, 1(1), 20-28.

Winarti, A. (2017). Persepsi Guru Terhadap Program Sertifikasi Guru. Quantum. Jurnal Inovasi Pendidikan Sains, 1(1). 